\title{
A Two Dimensional Infinite Element Model to Study Temperature Distribution in Human Dermal Regions due to Tumors
}

\author{
K.R. Pardasani and Madhvi Shakya \\ Department of Applied Mathematics, M.A.N.I.T., Bhopal, India
}

\begin{abstract}
In this study, a two dimensional infinite element model has been developed to study thermal effect in human dermal regions due to tumors. This model incorporates the effect of blood mass flow rate, metabolic heat generation and thermal conductivity of the tissues. The dermal region is divided into three natural layers, namely, epidermis, dermis and subdermal tissues. A uniformly perfused tumor is assumed to be present in the dermis. The domain is assumed to be finite along the depth and infinite along the breadth. The whole dermis region involving tumor is modelled with the help of triangular finite elements to incorporate the geometry of the region. These elements are surrounded by infinite domain elements along the breadth. Appropriate boundary conditions has been incorporated. A computer program has been developed to obtain the numerical results.
\end{abstract}

Key words: Rate of metabolic heat generation, thermal conductivity, blood mass flow rate, specific heat, tissue density

\section{INTRODUCTION}

A disturbance-say, an increase in metabolic heat production due to some abnormality-upsets the thermal balance. Heat is stored in the body and core temperature rises. Core temperature continues to rise and these responses continue to increase until they are sufficient to dissipate heat as fast as it is being produced, thus restoring heat balance and preventing further increases in body temperatures. The rise in core temperature that elicits heat-dissipating responses is sufficient to reestablish thermal balance. When the disturbance is too large, the whole body is no longer able to function. The study of relationships among various parameters, systems and organs of a human body are of clinical importance for biomedical scientists doctors,in diagnosis and cure of certain diseases like cancer etc and their treatment as well.

Perl gave a mathematical model of heat and mass distribution in tissues. He combined the Fick's second law of diffusion and Fick's perfusion principle along with heat generation term to deduce the model. The partial differential equation derived by him is given by:

$$
\rho c \partial T / \partial t=\operatorname{div}(\operatorname{Kgrad} T)+m_{b} c_{b}\left(T_{b}-T\right)+S
$$

The effect of blood flow and effect of metabolic heat generation are given by the terms $m_{b} c_{b}\left(T_{b}-T\right)$ and $S$, respectively.

Where, $\rho=$ tissue density, $c=$ specific heat of the tissue, $\mathrm{T}=$ unknown temperature, $\mathrm{t}=$ time, $\mathrm{K}=$ thermal conductivity, $\mathrm{m}_{\mathrm{b}}=$ blood mass flow rate, $\mathrm{c}_{\mathrm{b}_{-}}=$specific heat of blood, $\mathrm{T}_{\mathrm{b}}=$ blood temperature, $\mathrm{S}=$ rate of metabolic heat generation.
Perl $^{[1]}$ solved a simple case of equation (1) for a spherical symmetric heat source embedded in an infinite, tissue medium. Cooper and Trezek ${ }^{[2]}$ found an analytic solution of heat diffusion equation for brain tissue with negligible effect of blood flow and metabolic heat generation. Chao, Eisely and Yang ${ }^{[3]}$ and Chao and Yang ${ }^{[4]}$ applied steady state and unsteady state models with all the parameters as constant, to the problem of heat flow in the skin and subdermal tissues. Trezek and Cooper ${ }^{[5]}$ obtained a solution for a cylindrical symmetry considering all the parameters as constant and computed the thermal conductivity of the tissue. Saxena ${ }^{[6,7]}$ obtained an analytical solution to one dimensional problem taking position dependent values of blood mass flow and metabolic heat generation. Later on Saxena and Arya ${ }^{[8]}$ and Arya and Saxena ${ }^{[9]}$ initiated the use of finite element method for solving the problem of temperature distribution in three layered and six layered skin and subcutaneous tissues. Saxena and Bindra ${ }^{[10,11]}$ used quadratic shape functions in variational finite element method to solve a one dimensional steady state problem.

Later Saxena and Pardasani ${ }^{[12,13]}$ extended the application of analytical and finite element approach to the problems involving abnormalities like malignant tumors. Further Pardasani ${ }^{[12,14]}$ investigated the heat and water distribution problem in skin and subcutaneous tissues. Jas ${ }^{[15]}$ has also studied temperature distribution in cylindrical organs of human body involving tumors using finite element method.No study has been carried out for infinite domains. We ${ }^{[16]}$ studied thermal changes in infinite element domain of human peripheral regions due to tumors. 


\section{MATHEMATICAL MODEL}

For a two dimensional steady state case, the partial differential equation (1) for heat flow in skin and subcutaneous tissues takes the form:

$$
\frac{\partial}{\partial x} \frac{(K \partial T)}{\partial x}+\frac{\partial}{\partial y} \frac{(K \partial T)}{\partial y}+m_{b} c_{b}\left(T_{b}-T\right)+S=0
$$

The tumor is characterized by uncontrolled rates of metabolic heat generation. The normal tissues are characterized by self-controlled rate of metabolic heat generation. In view of this the metabolic term $\mathrm{S}$ in eqn.(2) can be broken into two parts i.e. $S=S_{1}+W$

Where, $\mathrm{S}_{1}$ and $\mathrm{W}$ are self controlled and uncontrolled rate of metabolic heat generation respectively.

We consider a rectangular composite region with boundaries $\mathrm{x}=\mathrm{a}, \mathrm{x}=\mathrm{b}$ and $\mathrm{y}=\mathrm{c}, \mathrm{y}=\mathrm{d}$ with the following conditions.

$$
\frac{\partial T}{\partial x}=\varepsilon, \text { at } \mathrm{x}=\mathrm{a},-\frac{\partial T}{\partial x}=\theta, \text { at } \mathrm{x}=\mathrm{b}
$$

$\mathrm{T}(\mathrm{x}, \mathrm{y})=\mathrm{T}_{\mathrm{b}}$, at $\mathrm{y}=\mathrm{c}$,

$-K \frac{\partial T}{\partial y}=h\left(T-T_{a}\right)+L E$, at $\mathrm{y}=\mathrm{d}$

The last condition incorporates the heat loss by radiation-convection and evaporation at the outer skin surface because the outer surface of the skin is exposed to the environment and heat loss takes place from this surface. where $h$ is heat transfer coefficient, $T_{a}$ is the atmospheric temperature, $\mathrm{L}$ and $\mathrm{E}$ are respectively the latent heat and rate of sweat evaporation. Also the human body maintains its core temperature at a uniform temperature $\left(37^{\circ} \mathrm{C}\right) . \mathrm{T}_{\mathrm{b}}$ is the body core temperature. The values of $\varepsilon$ and $\theta$ are taken depending on the outward normal flow from the boundaries at $\mathrm{x}=\mathrm{a}$ and $\mathrm{x}=\mathrm{b}$. The region is divided into sufficiently large number of two types of elements to match with geometry and to incorporate minute details of physiology. The triangular shaped finite elements and rectangular shaped infinite $^{[17]}$ elements. As the elements size is quite small, we take linear variation of temperature within each element.

The variational formulation of (2) for some general $\mathrm{e}^{\text {th }}$ element along with the boundary conditions (3) and (4) is given by:

$$
\begin{aligned}
& I^{(e)}=\frac{1}{2} \iint_{\Delta^{(e)}}\left[K^{(e)}\left(\frac{\partial T^{(e)}}{\partial x}\right)^{2}+K^{(e)}\left(\frac{\partial T^{(e)}}{\partial y}\right)^{2}\right. \\
& \left.+\left(m_{b} c_{b}\right)^{(e)}\left(T_{b}-T^{(e)}\right)^{2}-2\left(S_{1}+W^{(e)}\right) T^{(e)}\right] d x d y \\
& +\frac{1}{2} \int_{\tau_{1}}\left[h\left(T^{(e)}-T_{a}\right)^{2}+2 L E T^{(e)}\right] d x+\int_{\tau_{2}} \varepsilon^{(e)} T^{(e)} d y+\int_{\tau_{3}} \theta^{(e)} T^{(e)} d y
\end{aligned}
$$

Where, $\Delta^{(e)}$ is the region contained in the $e^{\text {th }}$ element.

Here the second integral of eq. (5) is valid for elements adjoining the outer skin surface, $\tau_{1}{ }^{(\mathrm{e})}$ being the boundary of the $\mathrm{e}^{\mathrm{th}}$ element exposed to the environment and it is zero for all other elements. In the same way third and fourth integrals are valid only for the elements adjoining the boundaries $\tau_{1}$ and $\tau_{2}$ respectively and taken equal to zero for the remaining elements. Following assumptions have been made for $\mathrm{K}^{(\mathrm{e})}$ and $\left(\mathrm{m}_{\mathrm{b}}\right.$ $\left.\mathrm{c}_{\mathrm{b}}\right)^{(\mathrm{e})}: \mathrm{K}^{(\mathrm{e})}=\mathrm{K}^{(\mathrm{e})}\left(\lambda_{1}{ }^{(\mathrm{e})}-\lambda_{2}{ }^{(\mathrm{e})} \mathrm{y}\right),\left(\mathrm{m}_{\mathrm{b}} \mathrm{c}_{\mathrm{b}}\right)^{(\mathrm{e})}=\mathrm{m}^{(\mathrm{e})}\left(\Phi_{1}{ }^{(\mathrm{e})}-\right.$ $\left.\Phi_{2}{ }^{(\mathrm{e})} \mathrm{y}\right)$

\section{For triangular finite elements:}

$\mathrm{T}^{(\mathrm{e})}=\mathrm{c}_{1}{ }^{(\mathrm{e})}+\mathrm{c}_{2}{ }^{(\mathrm{e})} \mathrm{x}+\mathrm{c}_{3}{ }^{(\mathrm{e})} \mathrm{y}$

Where $T^{(e)}$ is equal to $T_{i}, T_{j}$ and $T_{k}$ at the nodes of the $\mathrm{e}^{\text {th }}$ element. Thus we have

$\mathrm{T}_{\mathrm{i}}^{(\mathrm{e})}=\mathrm{c}_{1}{ }^{(\mathrm{e})}+\mathrm{c}_{2}{ }^{(\mathrm{e})} \mathrm{x}_{\mathrm{i}}+\mathrm{c}_{3}{ }^{(\mathrm{e})} \mathrm{y}_{\mathrm{i}}, \mathrm{T}_{\mathrm{j}}{ }^{(\mathrm{e})}=\mathrm{c}_{1}{ }^{(\mathrm{e})}+\mathrm{c}_{2}{ }^{(\mathrm{e})} \mathrm{x}_{\mathrm{j}}+\mathrm{c}_{3}{ }^{(\mathrm{e})} \mathrm{y}_{\mathrm{j}}$, $\mathrm{T}_{\mathrm{k}}{ }^{(\mathrm{e})}=\mathrm{c}_{1}{ }^{(\mathrm{e})}+\mathrm{c}_{2}{ }^{(\mathrm{e})} \mathrm{x}_{\mathrm{k}}+\mathrm{c}_{3}{ }^{(\mathrm{e})} \mathrm{y}_{\mathrm{k}}$

In matrix from this can be written as:

$\bar{T}^{(e)}=P^{(e)} C^{(e)}$

Where,

$$
C^{(e)}=\left[\begin{array}{l}
c_{1}{ }^{(e)} \\
c_{2}{ }^{(e)} \\
c_{3}{ }^{(e)}
\end{array}\right] P^{(e)}=\left[\begin{array}{ccc}
1 & x_{i} & y_{i} \\
1 & x_{j} & y_{j} \\
1 & x_{k} & y_{k}
\end{array}\right]
$$

Where, $\mathrm{C}^{(\mathrm{e})}$ is obtained from (7) and is given below:

$$
C^{(e)}=R^{(e)} \bar{T}^{(e)}, \text { Where } \mathrm{R}^{(\mathrm{e})}=\mathrm{P}^{(\mathrm{e})-1}
$$

The expression (6) may also be written as:

$\mathrm{T}^{(\mathrm{e})}=\mathrm{P}^{\mathrm{T}} \mathrm{C}^{(\mathrm{e})}$, Where $\mathrm{P}^{\mathrm{T}}=\left[\begin{array}{lll}1 & \mathrm{x} & \mathrm{y}\end{array}\right]$

On substituting the value of $\mathrm{C}^{(\mathrm{e})}$ from (8) in (9) we have

$T^{(e)}=P^{T} R^{(e)} \bar{T}^{(e)}$

The rate of metabolic heat generation is directly proportional to gradient of issue temperature. So when gradient of tissue temperature increases, rate of metabolic heat generation also increases and when the gradient of tissue temperature decreases, rate of metabolic heat generation also decreases. So the rate of self controlled metabolic heat generation for different triangular elements is prescribed below:

(i) If $y_{i}=y_{k}$ and $y_{i}>y_{k}$
$S^{(e)}=s{ }^{(e)}\left(\alpha^{(e)}-\beta^{(e)} y\right)\left[1+q^{(e)}\left(\frac{T_{i}+T_{k}}{2}-T_{j}\right)\right]$ 
(ii) If $\mathrm{y}_{\mathrm{i}}=\mathrm{y}_{\mathrm{k}}$ and $\mathrm{y}_{\mathrm{k}}>\mathrm{y}_{\mathrm{j}}$ $\mathrm{S}^{(\mathrm{e})}=\mathrm{s}^{(\mathrm{e})}\left(\alpha^{(\mathrm{e})}-\beta^{(\mathrm{e})} \mathrm{y}\right)\left[1+\mathrm{q}^{(\mathrm{e})}\left(\mathrm{T}_{\mathrm{j}}-\frac{\mathrm{T}_{\mathrm{i}}+\mathrm{T}_{k}}{2}\right)\right]$

(iii) If $y_{i}=y_{j}$ and $y_{k}>y_{j}$

$$
\mathrm{S}^{(\mathrm{e})}=\mathrm{s}^{(\mathrm{e})}\left(\alpha^{(\mathrm{e})}-\beta^{(\mathrm{e})} \mathrm{y}\right)\left[1+\mathrm{q}^{(\mathrm{e})}\left(\frac{\left.\left.\mathrm{T}_{\mathrm{i}}+\mathrm{T}_{\mathrm{i}}-\mathrm{T}_{\mathrm{k}}\right)\right]}{2}\right.\right.
$$

(iv) If $\mathrm{y}_{\mathrm{j}}=\mathrm{y}_{\mathrm{k}}$ and $\mathrm{y}_{\mathrm{k}}>\mathrm{y}_{\mathrm{i}}$

$$
S^{(e)}=s^{(e)}\left(\alpha^{(e)}-\beta^{(e)} y\right)\left[1+q^{(e)}\left(T_{i}-\frac{T_{i}+T_{k}}{2}\right)\right]
$$

For rectangular infinite elements: For $-1 \leq \xi \leq 1,-1$ $\leq \eta \leq 1$

$\mathrm{x}=\mathrm{M}_{1}(\xi, \eta) \mathrm{x}_{1}+\mathrm{M}_{2}(\xi, \eta) \mathrm{x}_{2}+\mathrm{M}_{3}(\xi, \eta) \mathrm{x}_{3}+\mathrm{M}_{4}(\xi, \eta) \mathrm{x}_{4}$

$\mathrm{y}=\mathrm{M}_{1}(\xi, \eta) \mathrm{y}_{1}+\mathrm{M}_{2}(\xi, \eta) \mathrm{y}_{2}+\mathrm{M}_{3}(\xi, \eta) \mathrm{y}_{3}+\mathrm{M}_{4}(\xi, \eta) \mathrm{y}_{4}$

Where the mapping functions $\mathrm{M}_{1}, \mathrm{M}_{2}, \mathrm{M}_{3}$ and $\mathrm{M}_{4}$ are given by :

$$
\begin{aligned}
& \mathrm{M}_{1}(\xi, \eta)=(1-\eta)(-\xi) /(1-\xi), \\
& \mathrm{M}_{2}(\xi, \eta)=(1+\eta)(-\xi) /(1-\xi) \\
& \mathrm{M}_{3}(\xi, \eta)=(1+\eta)(1+\xi) /[2(1-\xi)], \\
& \mathrm{M}_{4}(\xi, \eta)=(1-\eta)(1+\xi) /[2(1-\xi)] \\
& \mathrm{T}=\mathrm{N}_{1}(\xi, \eta) \mathrm{T}_{\mathrm{i}}+\mathrm{N}_{2}(\xi, \eta) \mathrm{T}_{\mathrm{j}}+\mathrm{N}_{3}(\xi, \eta) \mathrm{T}_{\mathrm{k}}+\mathrm{N}_{4}(\xi, \eta) \mathrm{T}_{1}
\end{aligned}
$$

Where the shape functions $\mathrm{N}_{1}, \mathrm{~N}_{2}, \mathrm{~N}_{3}$ and $\mathrm{N}_{4}$ are given by :

$\mathrm{N}_{1}(\xi, \eta)=(1-\eta)\left(\xi^{2}-\xi\right) / 4$,

$\mathrm{N}_{2}(\xi, \eta)=(1+\eta)\left(\xi^{2}-\xi\right) / 4$

$\mathrm{N}_{3}(\xi, \eta)=(1+\eta)\left(1-\xi^{2}\right) / 2$,

$\mathrm{N}_{4}(\xi, \eta)=(1-\eta)\left(1-\xi^{2}\right) / 2$

Let

$$
I=\sum_{e=1}^{N} I^{(e)}
$$

$\mathrm{N}=$ total no. of elements. Now I is minimized by differentiating it with respect to each of the nodal temperature and setting the derivatives equal to zero.

$$
\partial I / \partial \bar{T}=0
$$

Here, $\partial I / \partial \bar{T}$ denotes the differentiation of I with respect to each nodal temperature as given below:

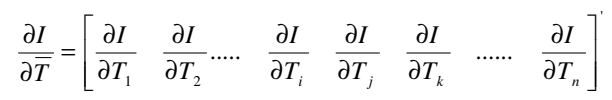

Also we define

$$
\bar{T}=\left[\begin{array}{lllllll}
T_{1} & T_{2} \ldots \ldots & T_{i} & T_{j} & T_{k} & \ldots \ldots & T_{n}
\end{array}\right]
$$

Here $\mathrm{n}=$ total number of nodal points.

\section{NUMERICAL RESULTS AND DISCUSSION}

Here a uniformly perfused tumor is assumed to be situated in the dermal region of the body. The skin and subcutaneous tissue (SST) region of human body has been divided into 10 layers. The epidermis consists of one layer. The dermis is divided into five layers and subdermal tissues are divided into four layers.The innermost layer is the core consisting of bone, muscles, large blood vessels etc.The vertical cross section of skin and sudbermal tissues with a solid tumor is shown in Fig. 1 which is discretized into 552 triangular finite elements and 10 rectangular infinite elements. The epidermal layer is discretized into 52 triangular elements with 2 infinite elements. The dermal layer is discretized into 292 elements with 5 infinite elements and also include 32 elements of tumor region. The subcutaneous tissues is discretized into 208 elements with 4 infinite elements Now using above assumptions and expressions, the integrals $\mathrm{I}^{(\mathrm{e})}$ are evaluated and assembled a given below:

562

$\mathrm{I}=\underset{\mathrm{e}=1}{\sum} \mathrm{I}^{(\mathrm{e})}$

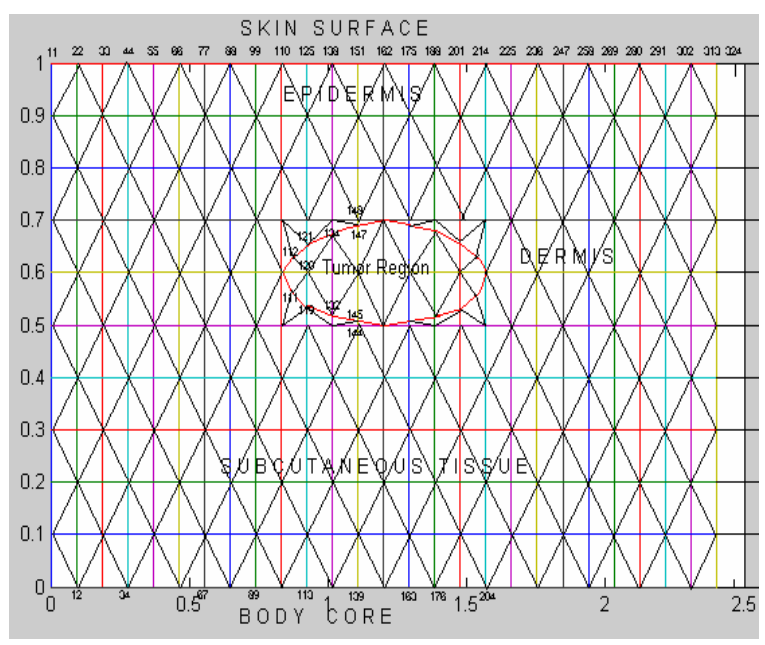

Fig. 1: Discretized section of skin

The integral I is extremised with respect to each nodal temperature $T_{i}(i=1(1) 322)$ to obtain a following set of algebraic equations in terms of nodal temperature $\mathrm{T}_{\mathrm{i}}(\mathrm{i}=1(1) 322)$.

$X \bar{T}=Y$

Here $\mathrm{X}, \mathrm{Y}$ and $\bar{T}$ are respectively the matrices of order $322 \times 322,322 \times 1$ and $322 \times 1$. A computer program has been developed for the entire problem in Microsoft Fortran Powerstation. Gaussian elimination method has been employed to solve the set of equations (16) to obtain nodal temperatures which give temperature profiles in each subregion.

The values of physical and physiological parameters have been taken from Cooper and Trezek ${ }^{[2]}$, Saxena and Bindra ${ }^{[10]}$ and Pardasani and Saxena ${ }^{[12,13]}$ as given below: 
$\mathrm{K}_{1}=0.030 \mathrm{Cal} \mathrm{cm}-\mathrm{min}^{-1} \cdot{ }^{\circ} \mathrm{C}, \mathrm{K}_{2}=0.0845 \mathrm{Cal} \mathrm{cm}-$ $\min ^{-1} .{ }^{\circ} \mathrm{C}, \mathrm{K}_{3}=0.060 \mathrm{Cal} \mathrm{cm}-\mathrm{min}^{-1} \cdot{ }^{\circ} \mathrm{C}$

$\mathrm{M}=0.003 \mathrm{Cal} \mathrm{cm} \mathrm{cm}^{3}-\mathrm{min}^{-1} \cdot{ }^{\circ} \mathrm{C}, \mathrm{S}=0.0357 . \mathrm{Cal} \mathrm{cm}{ }^{3}-$ $\min ^{-1}, \mathrm{~L}=579.0, \mathrm{~h}=0.009 \mathrm{Cal} \mathrm{cm}{ }^{2}-\mathrm{min}^{-1} .{ }^{\circ} \mathrm{C}$

The results have been computed for the following two cases of atmospheric temperatures and parameters $\mathrm{m}, \mathrm{S}$ and $\mathrm{E}$ have been assigned the values as given in Table 1.

Table 1: Values of $\mathrm{m}, \mathrm{S}$ and $\mathrm{E}$

\begin{tabular}{llll}
\hline $\begin{array}{l}\text { Atm. Temp } \\
\mathrm{T}_{\mathrm{a}}\left({ }^{\circ} \mathrm{C}\right)\end{array}$ & $\begin{array}{l}\mathrm{M}_{\max }=\left(\mathrm{m}_{b} \mathrm{c}_{b}\right)_{\max }= \\
\mathrm{m} \mathrm{cal} \mathrm{cm}{ }^{-3}-\mathrm{min} .{ }^{\circ} \mathrm{C}\end{array}$ & $\mathrm{S}_{\max }=\mathrm{s} \mathrm{cal} \mathrm{cm}^{-3} \min$ & $\mathrm{E}=\mathrm{gm} \mathrm{cm}^{-2} \min$ \\
\hline $15^{\circ} \mathrm{C}$ & 0.003 & 0.0357 & 0.0 \\
$23^{\circ} \mathrm{C}$ & 0.018 & 0.018 & $0.0,0.24 \times 10^{-3}$ \\
$33^{\circ} \mathrm{C}$ & 0.315 & 0.018 & $0.24 \times 10^{-3}$, \\
& & & $0.48 \times 10^{-3}$, \\
& & & $0.72 \times 10^{-3}$ \\
& & &
\end{tabular}

The following values have been assigned to physical and physiological parameters in each subregion.

\section{i. Epidermis}

$\lambda_{1}{ }^{(\mathrm{e})}=1 \lambda_{2}{ }^{(\mathrm{e})}=\mathrm{W}^{(\mathrm{e})}=\beta^{(\mathrm{e})}=0, \mathrm{~K}^{(\mathrm{e})}=0.03, \mathrm{~m}^{(\mathrm{e})}=0, \mathrm{q}^{(\mathrm{e})}$ $=2 /\left(\mathrm{T}_{\mathrm{a}}+\mathrm{T}_{\mathrm{b}}\right), \alpha^{(\mathrm{e})}=1, \mathrm{~s}^{(\mathrm{e})}=\mathrm{S} / 16$

\section{ii. Dermis}

$$
\lambda_{1}{ }^{(\mathrm{e})}=3, \lambda_{2}{ }^{(\mathrm{e})}=2.5, \mathrm{~K}^{(\mathrm{e})}=0.03, \phi_{1}{ }^{(\mathrm{e})}=4, \phi_{2}{ }^{(\mathrm{e})}=5,
$$
$\mathrm{m}^{(\mathrm{e})}=\mathrm{m}, \mathrm{W}^{(\mathrm{e})}=0, \mathrm{q}^{(\mathrm{e})}=2 /\left(\mathrm{T}_{\mathrm{a}}+\mathrm{T}_{\mathrm{b}}\right)$,

$$
\alpha^{(\mathrm{e})}=3.8, \beta^{(\mathrm{e})}=4.6, \mathrm{~s}^{(\mathrm{e})}=\mathrm{S}
$$

\section{iii. Subdermal Tissues}

$$
\lambda_{1}{ }^{(\mathrm{e})}=1, \lambda_{2}{ }^{(\mathrm{e})}=\mathrm{W}^{(\mathrm{e})}=\beta^{(\mathrm{e})}=0, \mathrm{~K}^{(\mathrm{e})}=0.06, \mathrm{~m}^{(\mathrm{e})}=
$$
$\mathrm{m}, \mathrm{q}^{(\mathrm{e})}=1 / \mathrm{T}_{\mathrm{b}}, \alpha^{(\mathrm{e})}=1, \mathrm{~s}^{(\mathrm{e})}=\mathrm{S}$

iv. Tumor region

$\lambda_{1}{ }^{(\mathrm{e})}=1, \lambda_{2}{ }^{(\mathrm{e})}=\phi_{2}{ }^{(\mathrm{e})}=\beta^{(\mathrm{e})}=\mathrm{s}^{(\mathrm{e})}=0, \mathrm{~K}^{(\mathrm{e})}=0.036, \phi_{1}{ }^{(\mathrm{e})}=$ $1, \mathrm{~m}^{(\mathrm{e})}=\mathrm{m}, \alpha^{(\mathrm{e})}=5, \mathrm{~W}^{(\mathrm{e})}=\mathrm{S}, \mathrm{q}^{(\mathrm{e})}=0$

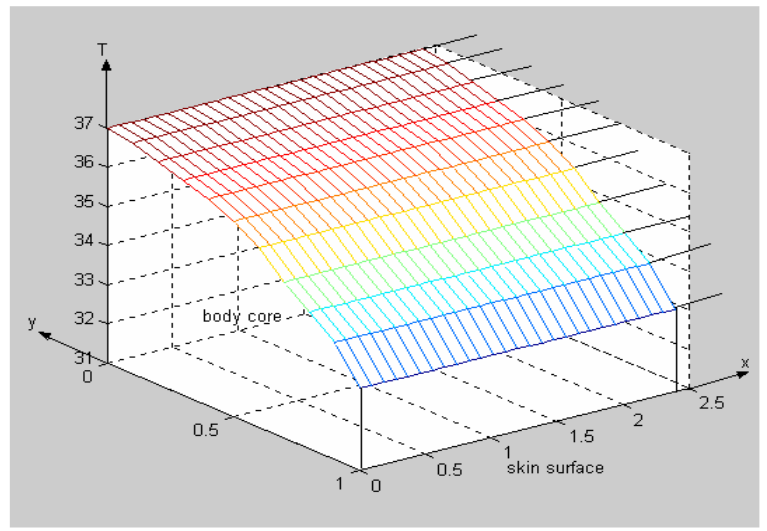

Fig. 2: Graph between temperature $\mathrm{T}\left(\right.$ in ${ }^{\circ} \mathrm{C}$ ) and $\mathrm{x}, \mathrm{y}$ (in $\mathrm{cm}$ ) at atmospheric temperature $\mathrm{T}_{\mathrm{a}}=15^{\circ} \mathrm{C}$ and $\mathrm{E}=0.0 \mathrm{gm} \mathrm{cm}^{-2}$ for normal case

The various temperature profiles have been studied. Figure 2 represents the temperature profiles for $\mathrm{T}_{\mathrm{a}}=15^{\circ} \mathrm{C}$ and $\mathrm{E}=0.0 \mathrm{gm} \mathrm{cm}^{-2}$ for a normal case (without tumor). Figure 3 shows temperature profiles for $\mathrm{T}_{\mathrm{a}}=23^{\circ} \mathrm{C}, \mathrm{E}=0.0 \mathrm{gm} \mathrm{cm}^{-2}$ for a normal case

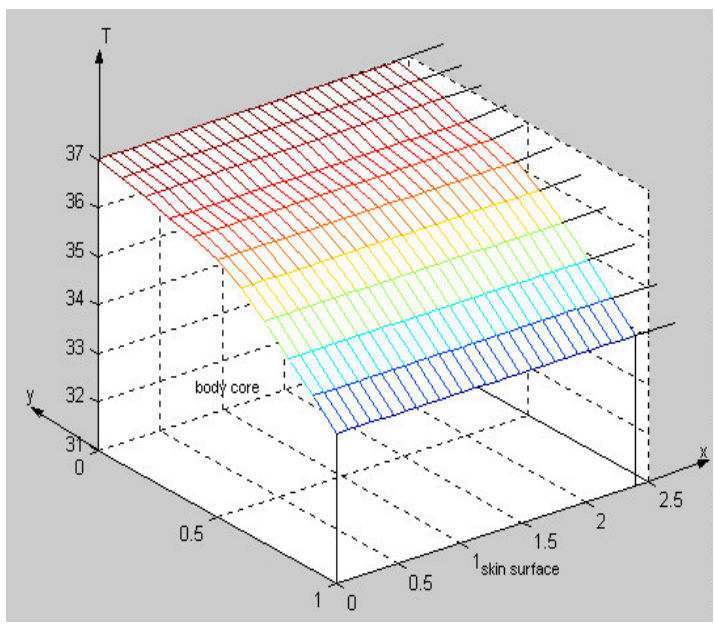

Fig. 3: Graph between temperature $\mathrm{T}$ (in ${ }^{\circ} \mathrm{C}$ ) and $\mathrm{x}$, y (in $\mathrm{cm})$ at atmospheric temp. $\mathrm{T}_{\mathrm{a}}=23^{\circ} \mathrm{C}$ and $\mathrm{E}=$ $0.0 \mathrm{gm} \mathrm{cm}^{-2}$ for normal case

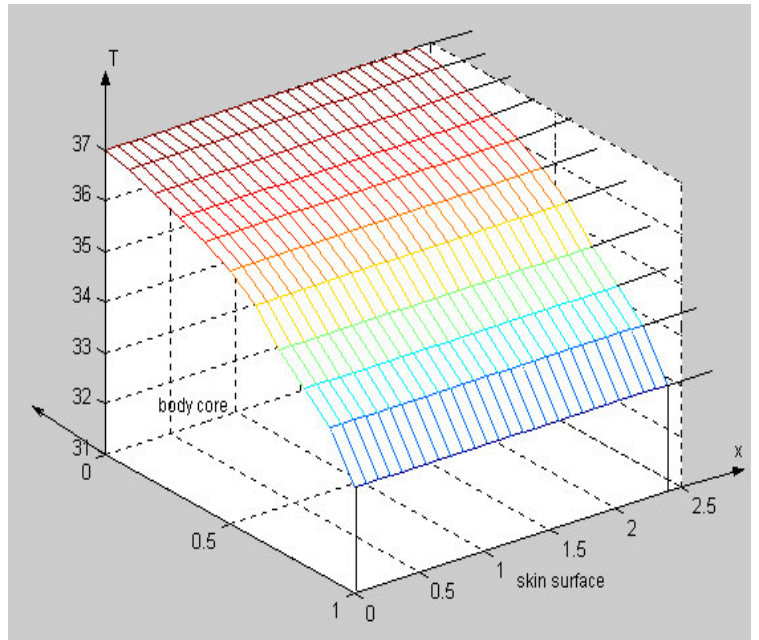

Fig. 4: Graph between temperature $\mathrm{T}$ (in ${ }^{\circ} \mathrm{C}$ ) and $\mathrm{x}$, y (in $\mathrm{cm})$ at atmospheric temp. $\mathrm{T}_{\mathrm{a}}=33^{\circ} \mathrm{C}$ and $\mathrm{E}=$ $0.24 \times 10^{-3} \mathrm{gm} \mathrm{cm}^{-2}$ for normal case

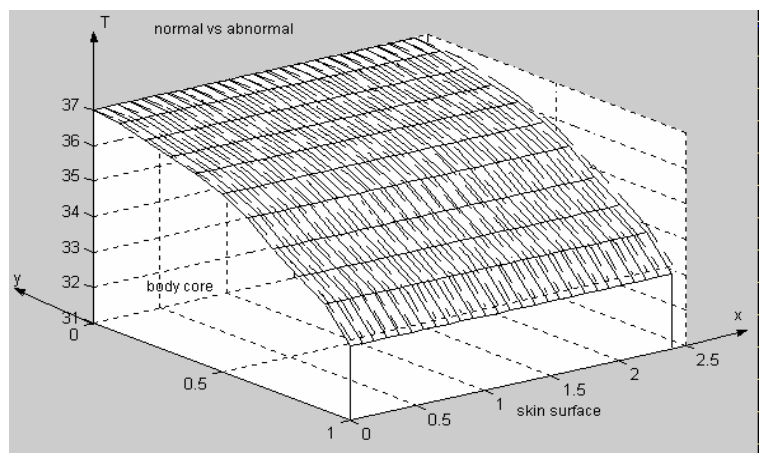

Fig. 5: Graph between temperature $\mathrm{T}$ (in ${ }^{\circ} \mathrm{C}$ ) and $\mathrm{x}$, y (in $\mathrm{cm})$ at atmospheric temp. $\mathrm{T}_{\mathrm{a}}=33^{\circ} \mathrm{C}$ and $\mathrm{E}=$ $0.24 \times 10^{-3} \mathrm{gm} \mathrm{cm}^{-2}$. Solid lines for normal tissues and dashed lines for abnormal tissues 
(without tumor). The fall in temperature profiles for a normal case (without tumor) is more for $\mathrm{T}_{\mathrm{a}}=15^{\circ} \mathrm{C}$ and $\mathrm{E}=0.0 \mathrm{gm} \mathrm{cm}^{-2}$ as compared to that for $\mathrm{T}_{\mathrm{a}}=23^{\circ} \mathrm{C}, \mathrm{E}=$ $0.0 \mathrm{gm} \mathrm{cm}^{-2}$. This may be because the heat loss is more from the skin surface at low atmospheric temperatures due to the increase in temperature gradient at the skin surface. Figure 4 shows temperature profiles for $\mathrm{T}_{\mathrm{a}}=$ $33^{\circ} \mathrm{C}, \mathrm{E}=0.24 \times 10^{-3} \mathrm{gm} \mathrm{cm}^{-2}$ for a normal case (without tumor). The temperature profiles for $\mathrm{T}_{\mathrm{a}}=15^{\circ} \mathrm{C}$ and $\mathrm{E}=$ $0.0 \mathrm{gm} \mathrm{cm}^{-2}$ and $\mathrm{T}_{\mathrm{a}}=33^{\circ} \mathrm{C}, \mathrm{E}=0.24 \times 10^{-3} \mathrm{gm} \mathrm{cm}^{-2}$ are close inspite of a difference of $18^{\circ} \mathrm{C}$ in atmospheric temperature and a small rate of sweat evaporation at higher temperature.This is due to large temperature gradient on the surface for low atmospheric temperature which causes more heat loss than that for smaller temperature gradients due to high atmospheric temperature. Figure 5 shows temperature profiles for $T_{a}$ $=33^{\circ} \mathrm{C}, \mathrm{E}=0.24 \times 10^{-3} \mathrm{gm} \mathrm{cm}^{-2}$ for a normal case (without tumor) and an abnormal case (with tumor). The temperature profiles fall down as we move away from body core to the skin surface. The numerical results for a normal case are comparable with those obtained by Saxena and Bindra ${ }^{[10]}$. An elevation in temperature profiles for skin and subdermal tissues with a tumor is observed while comparing the profiles for the normal and abnormal tissues. The maximum thermal disturbances are seen in the region between $y=0.5 \mathrm{~cm}$ and $y=0.7 \mathrm{~cm}$. The points of change in the slopes of the curves are actually the junction of normal tissues and tumor region. This information is useful for justifying the boundaries of tumor region and normal region. Such models can be developed to generate the thermal information which may be useful for biomedical scientists for diagnosis and treatment of cancer.

\section{REFERENCES}

1. Perl, W., 1963. An extension of the diffusion equation to include clearance by capillary blood flow. Ann. NY. Acad. Sci., 108: 92-105.

2. Cooper, T.E. and G.J. Trezek, 1972. A probe technique for determining the thermal conductivity of tissue. J. Heat Trans., ASME, 94: 133-140.

3. Chao, K.N., J.G. Eisley and W.J. Yang, 1973. Heat and water migration in regional skin and subcutaneous tissues. Bio. Mech., ASME, pp: 69-72.

4. Chao, K.N. and W.J. Yang, 1975. Response of skin and tissue temperature in Sauna and steam baths. Bio. Mech. Symp. ASME, pp: 69-71.

5. Trezek, G.J. and T.E. Cooper, 1968. Analytical determination of cylindrical source temperature fields and their relation to thermal diffusivity of brain tissues. Thermal Problems in Biotechnol., ASME, NY., pp: 1-15.
6. Saxena, V.P., 1979. Effect of blood flow on temperature distribution in human skin and subdermal tissues. Proc. 9th Natl. Conf. Fluid Mechanics and Fluid Power, pp: 156-161.

7. Saxena, V.P., 1983. Temperature distribution in human skin and subdermal tissues. J. Theo. Biol., pp: 277-286.

8. Saxena, V.P. and D. Arya, 1981. Steady state heat distribution in epidermis, dermis and subdermal tissues. J. Theor. Biol., 89: 423-432.

9. Arya, D. and V.P. Saxena, 1981. Application of variational finite element method in the measurement of thermal conductivity of human skin and subdermal tissues. Proc. Natl. Acad. Sci., India, 51(A), pp: 447-450.

10. Saxena, V.P. and J.S. Bindra, 1984. Steady state temperature distribution in dermal blood flow, perspiration and self controlled metabolic heat generation. Indian. J. Pure and Appl. Math., 15: 3142.

11. Saxena, V.P. and J.S. Bindra, 1989. Psuedo analytic finite partition approach to temperature distribution problems in human limbs. Intl. J. Math and Math. Sci. USA., 12: 403-408.

12. Pardasani, K.R. and V.P. Saxena, 1991. Effect of dermal tumor on temperature distribution in skin with variable blood flow. Bull. Math. Biol., USA., 53: 525-536.

13. Pardasani, K.R. and V.P. Saxena, 1989. Exact solutions to temperature distribution problem in annular skin layers. Bull. Calcutta Math. Soc., 81: 1-8.

14. Pardasani, K.R., 1988. Mathematical investigations on human physiological heat flow problems with special relevance to cancerous tumors. Ph.D. Thesis, Jiwaji University Gwalior, pp: 115-210.

15. Jas, P., 2000. Finite element approach to the thermal study of malignancies in cylindrical human organs. Ph.D. Thesis, Barkhatullah University, Bhopal.

16. Pardasani, K.R. and M. Shakya, 2004. Two dimensional infinite element model of temperature distribution in human peripheral regions due to uniformly perfused tumors. Proc. Natl. Conf. Biomechanics, IIT, New Delhi, Nov. 19-21.

17. Marques, J.M.M.C. and D.R.J. Owen. Infinite elements in quasi-static materially non-linear problems. Computers \& Structures, 18: 739-751. 